\title{
Prognostic significance of tumor-infiltrating T-lymphocytes in primary and metastatic lesions of advanced stage ovarian cancer
}

\author{
Ninke Leffers • Marloes J. M. Gooden • Renske A. de Jong • Baukje-Nynke Hoogeboom • \\ Klaske A. ten Hoor • Harry Hollema • H. Marieke Boezen · Ate G. J. van der Zee • \\ Toos Daemen · Hans W. Nijman
}

Received: 11 June 2008 / Accepted: 21 August 2008 / Published online: 13 September 2008

(c) The Author(s) 2008. This article is published with open access at Springerlink.com

\begin{abstract}
Purpose Ovarian cancer patients with intra-tumoral $\mathrm{CD}^{+}$ T-lymphocytes in primary tumor tissue have a better prognosis. This study aims to analyze the presence and relative influence of three important T-lymphocyte subsets, tumorinfiltrating $\mathrm{CD}^{+}$cytotoxic T-lymphocytes (CTL), CD45R0 $0^{+}$ memory T-lymphocytes, and FoxP $3^{+}$regulatory T-lymphocytes (Treg), in primary tumor tissue and omental metastases of patients with ovarian cancer.

Experimental design The number of $\mathrm{CD}^{+}, \mathrm{CD} 45 \mathrm{R} 0^{+}$, and FoxP ${ }^{+}$T-lymphocytes was determined by immunohistochemistry on a tissue micro array containing ovarian
\end{abstract}

Ninke Leffers and Marloes J. M. Gooden contributed equally.

N. Leffers · M. J. M. Gooden · R. A. de Jong $\cdot$ B.-N. Hoogeboom

K. A. ten Hoor · A. G. J. van der Zee · H. W. Nijman ( $\square)$

Department of Gynecological Oncology,

University Medical Center Groningen, University of Groningen,

PO 30.001, 9700 RB Groningen, The Netherlands

e-mail: h.w.nijman@og.umcg.nl

N. Leffers

e-mail: n.leffers@og.umcg.nl

B.-N. Hoogeboom · T. Daemen

Department of Medical Microbiology,

Molecular Virology Section,

University Medical Center Groningen,

University of Groningen, Groningen, The Netherlands

H. Hollema

Department of Pathology,

University Medical Center Groningen,

University of Groningen, Groningen, The Netherlands

H. M. Boezen

Department of Epidemiology,

University Medical Center Groningen,

University of Groningen, Groningen, The Netherlands tumor tissue and/or omental metastases obtained at primary debulking surgery from 306 FIGO stage I-IV ovarian cancer patients. Immunohistochemistry data were correlated to clinicopathological parameters and survival data.

Results High number of $\mathrm{CD}^{+} \mathrm{CTL}$ and a high $\mathrm{CD}^{+} /$ $\mathrm{FoxP}^{+}$ratio in ovarian-derived tumor tissue were associated with increased disease-specific survival and proved to be independent prognostic factors in multivariate analyses. In advanced stage patients, the presence of $\mathrm{CD}^{+} \mathrm{CTL}$, CD45R0 $0^{+}$memory T-lymphocytes, FoxP $3^{+}$Treg or a high $\mathrm{CD}^{+} / \mathrm{FoxP}^{+}$ratio in ovarian-derived tumor tissue was associated with an increased disease specific survival in univariate analysis, as was the presence of $\mathrm{CD} 45 \mathrm{R} 0^{+}$ memory T-lymphocytes and FoxP3 ${ }^{+}$Treg in omental metastases. Furthermore, in advanced stage patients $\mathrm{CD} 8^{+}$ cytotoxic and FoxP $3^{+}$regulatory T-lymphocytes infiltrating ovarian-derived tumor tissue were independent predictors of increased prognosis.

Conclusions T-lymphocytes infiltrating primary and metastatic ovarian cancer sites are associated with improved prognosis. These associations are especially distinct in advanced stage patients, underlining the potential for immunotherapy as a broadly applicable therapeutic strategy.

Keywords Ovarian cancer $\cdot$ Memory T-lymphocytes · Omental metastasis

\section{Introduction}

Ovarian cancer is the most frequent cause of death from gynecological malignancies, with an overall mortality of $60 \%$. Due to its lack of specific symptoms, $70 \%$ of patients present with advanced disease. Initial treatment consists of 
cytoreductive surgery and platinum based chemotherapy. Even when initial treatment is successful, many patients relapse. There is no curative secondary treatment in case of residual disease after chemotherapy or relapse [13, 22]. Therefore, new therapeutic strategies are under investigation [1]. Immunotherapy is one of these strategies and has yielded especially promising results in fundamental and animal research. However, clinical applications have only shown limited efficacy. Further knowledge is necessary to develop strategies to increase clinical efficacy of immunotherapy.

Tumor-infiltrating lymphocytes (TIL) were found to correlate with improved prognosis in several types of cancer $[8,12,14,25,29,33]$. The presence of TIL is considered a reflection of the immune response to the tumor. However, not all T-lymphocyte subsets contribute equally to this observed positive effect on prognosis. Invasion by cytotoxic T-lymphocytes (CTL) has been found to be advantageous in ovarian cancer [25] and several other types of cancer [15, $19,20,26]$. The role of $\mathrm{CD}^{+} \mathrm{T}$-lymphocytes is ambiguous. Non-regulatory $\mathrm{CD} 4^{+}$helper T-lymphocytes, especially of the Th1 subset, are considered to be beneficial in cancer, in general [32]. Regulatory CD4+ ${ }^{+}$-lymphocytes (Treg) have a physiological function in preventing autoimmunity. They may induce peripheral tolerance, and in doing so, suppress immune responses. In cancer, Treg traffic to tumors as a result of chemokines produced by tumor cells and microenvironmental macrophages [9]. There, they suppress effector T-lymphocytes by secreting transforming growth factor $\beta$ (TGF- $\beta$ ) and interleukin 10 (IL-10) or by direct cell-cell contact [9]. Treg have been found to unfavorably influence prognosis in ovarian cancer [9, 30]. From a functional point of view, the ratio between effector T-lymphocytes and regulatory T-lymphocytes may be even more interesting, as was demonstrated by Sato et al. [25] who showed that high ratios of CTL/helper T-lymphocytes and CTL/Treg were of prognostic significance, whereas no significant association between the number of tumor infiltrating T-lymphocytes in general or subsets (Treg/helper T-lymphocytes) and overall survival were found in ovarian cancer. A less well studied T-lymphocyte subset are memory T-lymphocytes, which may arise after the initial immune response against an antigen. In cancer, memory T-lymphocytes mediate longterm immunity against tumors [21]. The presence of intra-tumoral memory T-lymphocytes is associated with increased survival in hepatocellular [6] and colorectal cancer $[12,21]$. To our knowledge, no studies have been published investigating the presence of memory $\mathrm{T}$ lymphocytes in ovarian cancer. In summary, patients with tumor-infiltrating T-lymphocytes mount an immune response against their tumor, the success of which seems to depend on the relative concentrations of different T-cell subtypes.
No reports have been published describing possible differences in T-lymphocyte infiltration patterns between primary tumor sites and metastases. The omentum is a frequent site for metastases in ovarian cancer, due to the displacement of tumor cells by the peritoneal fluid stream. We decided to study the presence of infiltrating T-lymphocytes in omental metastases, which was greatly facilitated by the fact that omentectomy is a routine part of cytoreductive surgery. We compared the results with infiltrating T-lymphocytes in tissue taken from the primary ovarian tumor.

Aims of the present study were to determine the presence of $\mathrm{CD}^{+} \mathrm{CTL}, \mathrm{CD} 45 \mathrm{R} 0^{+}$memory $\mathrm{T}$-lymphocytes, and FoxP $^{+}$Treg in primary tumor specimens and simultaneous omental metastases of patients with ovarian cancer and to determine their prognostic impact.

\section{Methods}

\section{Patients}

As of 1985, the Department of Gynecological Oncology at the University Medical Center Groningen (UMCG) keeps a computerized database of patients with malignant epithelial ovarian cancer treated at this hospital at any time point, during the course of their disease, prospectively collecting information on clinicopathologic characteristics and follow-up.

For this study, ovarian cancer patients were selected if primary surgery was performed by a gynecological oncologist from the UMCG between May 1985 and June 2006 and if paraffin-embedded ovarian and omental tumor tissue was available.

Patients were staged according to FIGO classification [7]. Tumors were graded and classified according to WHO criteria by a gynecological pathologist [27]. Adjuvant chemotherapy consisted of different platinum-based treatment regimens. Response to chemotherapy was evaluated according to WHO criteria [31]. After treatment, patients were followed-up for at least 10 years with gradually increasing intervals. Follow-up data were completed for all patients until January 2007.

\section{Institutional Review Board Approval}

For the present study, all relevant data were retrieved from our computerized database into a separate anonymous database. In this separate password-protected database, patient identity was protected by study-specific, unique patient codes, which were only known to two dedicated data managers, who also have daily responsibility for the larger database. In case of uncertainties with respect to clinicopathological and follow-up data, the larger databases could 
only be checked through the data managers, thereby ascertaining the protection of patients' identity. According to Dutch law no approval from our IRB was needed.

\section{Tissue micro arrays}

Tissue micro arrays (TMA) were constructed as described in previous studies [16, 24]. In brief, paraffin-embedded tissue blocks containing tumor in ovarian and omental tissue, and corresponding hematoxylin \& eosin (H\&E) stained slides were retrieved from the pathology archives. Representative areas of tumor were marked on the H\&E stained slides. Next, using these H\&E slides for reference, four $0.6 \mathrm{~mm}$ core biopsies were taken from each tumor specimen and arrayed on a recipient paraffin block using a tissue microarrayer (Beecher instruments, Silver Spring, Maryland, USA). Adhesion of cores to the recipient block was accomplished by placing the blocks in a $37^{\circ} \mathrm{C}$ oven for $15 \mathrm{~min}$. For staining, $4 \mu \mathrm{m}$ sections were cut from each TMA block. H\&E staining was performed to verify the presence of tumor in the arrayed samples.

\section{Immunohistochemistry}

TMA sections were stained with mouse monoclonal antibodies recognizing CTL (anti-CD8; Dako cytomation, Glostrup, Denmark), memory T-lymphocytes (antiCD45R0 clone OPD4; Labvision, Fremont, CA, USA) and Treg (anti-FoxP3 m22509, Abcam, Cambridge, UK). In brief, TMA sections were dewaxed in xylene and rehydrated using graded concentrations of ethanol to distilled water. After antigen retrieval, endogenous peroxidase activity was blocked by submersion of sections in a $0.3 \%$ $\mathrm{H}_{2} \mathrm{O}_{2}$ solution for $30 \mathrm{~min}$. Sections were incubated with the primary antibody for $60 \mathrm{~min}$ at room temperature (dilutions: anti-CD8 1:20; anti-CD45R0 1:50; anti-FoxP3 1:100). Sections incubated with anti-CD45R0 and antiFoxP3 were subsequently incubated with DAKO Envision+ for $30 \mathrm{~min}$. For sections incubated with anti-CD8, RAM ${ }^{\mathrm{po}}$ (dilution 1:100) and $\mathrm{GAR}^{\text {po }}$ (dilution 1:100) were used as secondary and tertiary antibodies, respectively. The antigen-antibody reactions were visualised with 3,3'diaminobenzidine or NovaRED ${ }^{\mathrm{TM}}$ (Vector Laboratories, Burlingame) for anti-FoxP3 staining. Sections were counterstained with hematoxylin.

\section{Scoring}

All stainings were scored independently by two observers. Observers had no prior knowledge of clinicopathological information. For the anti-CD8 and anti-CD45R0 staining, the number of cells with membrane staining within tumor epithelium was counted for each core. For the anti-FoxP3 staining, the number of cells with nuclear staining within tumor-islets in every core was counted. To obtain a high concordance rate with whole tissue slides, we decided that minimally two cores with a minimum of $20 \%$ tumor tissue had to be present on the TMA for a sample to be entered into analysis [24]. Subsequently, we calculated the number of intra-tumoral cells per $0.283 \mathrm{~mm}^{2}$ of tumor (i.e., one whole core consisting of $100 \%$ tumor tissue), to correct for differences in the amount of tumor tissue and to standardize the analysis. This calculation entailed dividing the total number of intra-tumoral cells in cores containing $\geq 20 \%$ of tumor by the total percentage of tumor tissue present in these cores.

\section{Statistics}

The distribution of all TIL subtypes was positively skewed. For further analysis, we therefore decided to categorize patients using the bottom tertile (p33) as a cut-off value [25]. However, when the bottom tertile equaled zero, a subdivision based on the presence or absence of these cells was made for further analysis. Associations between clinicopathological characteristics and intra-tumoral T-lymphocytes were tested using the $\chi^{2}$ test. Differences in numbers of tumor-infiltrating T-lymphocytes between primary ovarian tumor tissue and omental metastases were tested using Wilcoxon Signed Ranks test. Disease-specific survival (DSS) was defined as date of surgery until death due to ovarian cancer or date of last follow-up. DSS was estimated using Kaplan Meier and Log Rank test, it was used to assess for survival differences between groups. Cox proportional hazards models were used for multivariate analyses and were stratified for type of chemotherapy. Only variables that were significantly associated with DSS in the univariate analyses were entered into multivariate analyses. Survival analyses were performed in the total population as well as in a subgroup which included all advanced stage patients. For all tests, $p$ values $<0.05$ were considered significant. All $p$ values were tested two-sided. All statistical analyses were performed using SPSS 14.0 software package for windows (SPSS Inc., Chicago, IL, USA).

\section{Results}

Study population

From a total of 306 ovarian cancer patients, sufficient paraffin-embedded ovarian and/or omental tissue containing epithelial ovarian carcinoma was available for construction of the TMA (Fig. 1a). Tumor-containing ovarian tissue was available from 270 patients. From $111(41.1 \%)$ of these patients tumor-containing omental tissue was also available. 
Fig. 1 Immunohistochemical staining of tumor-infiltrating T-lymphocytes in ovarian cancer tissue. a Flow diagram showing the type of tissue analyzed and the percentage of patients lost from analysis. Patients were excluded from analysis when less than two tissue cores with at least $20 \%$ tumor were present for evaluation. b Intra-tumoral $\mathrm{CD}^{+}$T-lymphocytes, $\mathbf{c}$ CD45R $0^{+} \mathrm{T}$-lymphocytes, d FoxP3 ${ }^{+}$T-lymphocytes at $400 \times$ magnification
A
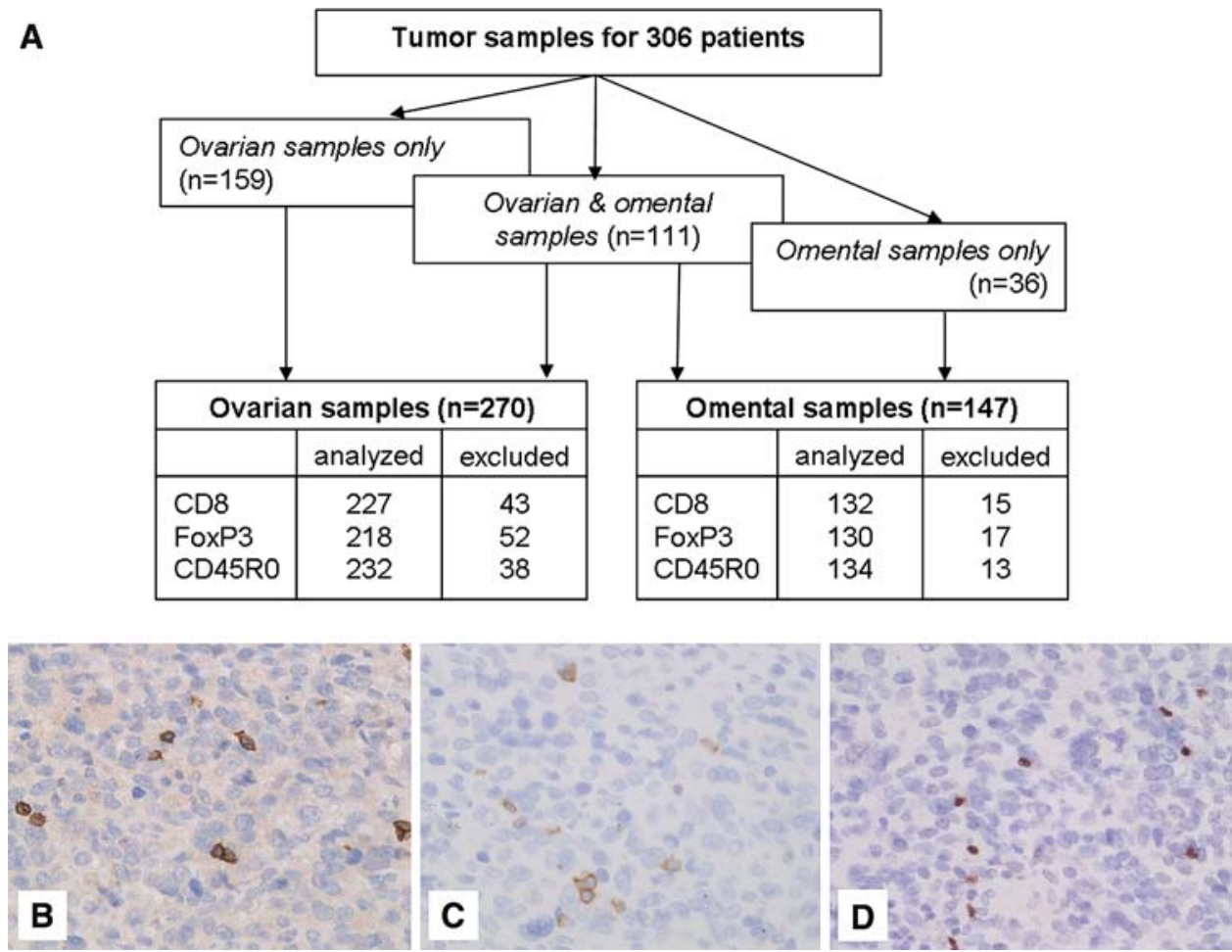

Only tumor-containing omental tissue was available from an addition of 36 patients. Clinicopathological characteristics of patients are summarized in Table 1. Forty-two patients did not receive chemotherapy, 28 of them were diagnosed with FIGO stage I disease. The remaining 14 patients were either not fit or unwilling to receive chemotherapy. Of the patients treated with chemotherapy $89.5 \%$ received a platinum-based regimen. The median survival for all patients was 37.4 months with an estimated 5-year disease-specific survival of $41 \%$.

\section{Tumor-infiltrating T-lymphocytes}

Intra-tumoral $\mathrm{CD}^{+}, \mathrm{CD}_{4} 5 \mathrm{R}^{+}$, and $\mathrm{FoxP}^{+} \mathrm{T}$-cells were present in $91.2,47.0$, and $53.2 \%$ of primary ovarian tissue, respectively (representative examples in Fig. 1b-d), while intra-tumoral $\mathrm{CD}^{+}, \mathrm{CD}_{4} \mathrm{R} 0^{+}$, and $\mathrm{FoxP}^{+}{ }^{+} \mathrm{T}$-cells were present in $96.2,49.3$ and $73.1 \%$ of omental metastases, respectively.

In both ovarian and omental derived tumor tissue, the number of tumor-infiltrating T-lymphocytes was positively associated with each other for all subtypes (Tables 2, 3). Although the median number of tumor-infiltrating T-lymphocytes was higher for omental than ovarian tissue, no differences in intra-tumoral T-lymphocytes were observed between ovarian and omental tumor tissue within patients for whom both samples were available (data not shown).
Association of tumor-infiltrating lymphocytes with clinicopathological parameters

Tables 2 and 3 show the relationship of clinicopathological parameters to the presence of intra-tumoral TIL in ovary and omentum derived tumor tissue, respectively. In ovarian tissue, the presence of $\mathrm{FoxP}^{+}$cells was positively associated with advanced stage disease $(p=0.031)$. Furthermore, patients with poorly differentiated tumors were more likely to have intra-tumoral $\mathrm{FoxP}^{+}$cells compared to patients with well-differentiated tumors $(p=0.011)$. Also, patients younger than 59 years at time of diagnosis were more likely to have a low $\mathrm{CD}^{+} / \mathrm{CD} 45 \mathrm{R} 0^{+}$ratio than older patients (data not shown: 48.5 vs. $34.3 \%, p=0.036$ ).

In omental metastases, high $\mathrm{CD} 8^{+} \mathrm{T}$-cell numbers were associated with $<2 \mathrm{~cm}$ residual disease after primary debulking surgery $(p=0.035)$. A similar association was found for $\mathrm{FoxP}^{+}$cells, which were more often present in patients with residual disease of $<2 \mathrm{~cm}(p=0.028)$.

\section{Survival analysis}

In agreement with expectations, well-known prognostic factors such as age $\geq 59$ years, advanced stage disease, poorly differentiated tumors, serous tumors and $\geq 2 \mathrm{~cm}$ residual disease after primary debulking surgery were associated with a shorter disease-specific survival (data not shown). Furthermore, univariate analysis of disease-specific 
Table 1 Clinicopathological characteristics and survival data

\begin{tabular}{|c|c|c|c|c|}
\hline \multirow[t]{33}{*}{$\begin{array}{l}\text { Table } 1 \text { Clinicopathological } \\
\text { characteristics and survival data }\end{array}$} & & Total $(n=306)$ & $\begin{array}{l}\text { Primary ovarian } \\
\text { cancer }(n=270)\end{array}$ & $\begin{array}{l}\text { Metastatic omental- } \\
\text { ovarian cancer }(n=147)\end{array}$ \\
\hline & Age (years) & & & \\
\hline & Mean (SD) & $57.2(13.5)$ & $56.8(13.8)$ & $59.6(12.2)$ \\
\hline & DSS (months) & & & \\
\hline & Median $(95 \% \mathrm{CI})$ & $37.4(25.6-49.2)$ & $45.4(31.1-59.8)$ & $20.4(14.3-27.3)$ \\
\hline & FIGO Stage & & & \\
\hline & Stage I & $67(21.9 \%)$ & $67(24.8 \%)$ & \\
\hline & Stage II & $24(7.8 \%)$ & $25(9.3 \%)$ & \\
\hline & Stage III & $171(55.9 \%)$ & $145(53.7 \%)$ & $116(78.9 \%)$ \\
\hline & Stage IV & $42(13.7 \%)$ & $32(11.9 \%)$ & $30(20.4 \%)$ \\
\hline & Missing & $2(0.7 \%)$ & $1(0.4 \%)$ & $1(0.7 \%)$ \\
\hline & Tumor type & & & \\
\hline & Serous & $171(55.9 \%)$ & $147(54.4 \%)$ & $105(71.4 \%)$ \\
\hline & Mucinous & $36(11.8 \%)$ & $35(13.0 \%)$ & $6(4.1 \%)$ \\
\hline & Endometroid & $41(13.4 \%)$ & $38(14.1 \%)$ & $13(8.8 \%)$ \\
\hline & Clear cell & $21(6.9 \%)$ & $18(6.7 \%)$ & $7(4.8 \%)$ \\
\hline & Adenocarcinoma & $13(4.2 \%)$ & $10(3.7 \%)$ & $5(3.4 \%)$ \\
\hline & Mixed tumours & $15(4.9 \%)$ & $14(5.2 \%)$ & $5(3.4 \%)$ \\
\hline & Other & $9(2.9 \%)$ & $8(3.0 \%)$ & $6(4.1 \%)$ \\
\hline & Tumor grade & & & \\
\hline & Grade I & $52(17.0 \%)$ & $51(18.9 \%)$ & $6(4.1 \%)$ \\
\hline & Grade II & $80(26.1 \%)$ & $76(28.1 \%)$ & $28(19.0 \%)$ \\
\hline & Grade III & $135(44.1 \%)$ & $113(41.9 \%)$ & $91(61.9 \%)$ \\
\hline & Undifferentiated & $14(4.6 \%)$ & $11(4.1 \%)$ & $9(6.1 \%)$ \\
\hline & Missing & $25(8.2 \%)$ & $19(7.0 \%)$ & $13(8.8 \%)$ \\
\hline & Residual disease & & & \\
\hline & $<2 \mathrm{~cm}$ & $162(52.9 \%)$ & $157(58.1 \%)$ & $47(32.0 \%)$ \\
\hline & $\geq 2 \mathrm{~cm}$ & $123(40.2 \%)$ & $92(34.1 \%)$ & $94(63.9 \%)$ \\
\hline & Missing & $21(6.9 \%)$ & $21(7.8 \%)$ & $6(4.1 \%)$ \\
\hline & Chemotherapy & & & \\
\hline & No chemotherapy & $42(13.7 \%)$ & $40(14.8 \%)$ & $12(8.2 \%)$ \\
\hline & Platinum-containing & $117(38.2 \%)$ & $104(38.5 \%)$ & $48(32.7 \%)$ \\
\hline & Platinum and taxane containing & $113(36.9 \%)$ & $96(35.6 \%)$ & $69(46.9 \%)$ \\
\hline \multirow{2}{*}{$\begin{array}{l}\text { DSS disease-specific survival, } \\
\text { FIGO International Federation } \\
\text { of Gynaecology and Obstetrics }\end{array}$} & Other regimen & $27(8.8 \%)$ & $24(8.9 \%)$ & $16(10.9 \%)$ \\
\hline & Unknown & $7(2.3 \%)$ & $6(2.2 \%)$ & $2(1.4 \%)$ \\
\hline
\end{tabular}

DSS disease-specific survival, FIGO International Federation of Gynaecology and Obstetrics survival showed an initial survival advantage for patients with high numbers of intra-tumoral $\mathrm{CD}^{+}$cytotoxic T-lymphocytes in ovarian-derived tumor tissue, which subsides after 10 years of follow-up ( $p=0.042$, Fig. 2a). Diseasespecific survival was not influenced by the presence of $\mathrm{CD} 45 \mathrm{R} 0^{+}$memory $\mathrm{T}$-lymphocytes, $\mathrm{FoxP}^{+}$regulatory $\mathrm{T}$ lymphocytes in ovarian tissue. However, median DSS of patients with a high $\mathrm{CD}^{+} / \mathrm{FoxP}^{+}$ratio in ovarian-derived tumor tissue was twice as high as for patients with a low $\mathrm{CD}^{+} / \mathrm{FoxP}^{+}$ratio $(50.0$ vs. 23.0 months, $p=0.014$, Fig. 2b). For the $\mathrm{CD} 8^{+} / \mathrm{CD} 45 \mathrm{R} 0^{+}$ratio a trend was observed towards a longer median DSS in patients with a high ratio (51.7 vs. 30.9 months, $p=0.056$ ).
We subsequently repeated univariate survival analyses using a subgroup consisting of patients with advanced stage disease. Interestingly, in this subgroup a prolonged median DSS was observed for all T-lymphocyte subsets studied in ovarian-derived tumor tissue, except for the $\mathrm{CD} 8^{+} /$ $\mathrm{CD} 45 \mathrm{R}^{+} 0^{+}$ratio (30.5 vs. 15.6 months, $p=0.076$ ), i.e., $\mathrm{CD} 45 \mathrm{R}^{+}{ }^{+}$lymphocytes $(n=155,37.3$ vs. 16.4 months, $p=0.009$, Fig. 2c), $\mathrm{CD}^{+}$lymphocytes $(n=150,30.3$ vs. 12.2 months, $p=0.012$, Fig. 2d), FoxP3 ${ }^{+}$lymphocytes ( $n=149,30.3$ vs. 14.0 months, $p=0.008$, Fig. $2 \mathrm{e}$ ) and a high $\mathrm{CD}^{+} / \mathrm{FoxP}^{+}$ratio $(n=146,30.3$ vs. 14.6 months; $p=0.016$, Fig. 2f). Similarly, univariate analysis of disease-specific survival differences based on the presence of 
Table 2 Relationship of tumor-infiltrating lymphocytes in ovarian tissue to clinicopathological parameters and each other $(N, \%)$

\begin{tabular}{|c|c|c|c|c|c|c|c|c|c|}
\hline & \multicolumn{3}{|c|}{$\mathrm{CD}^{+}$T-lymphocyte } & \multicolumn{3}{|c|}{ CD45R0 $0^{+} \mathrm{T}$-lymphocyte } & \multicolumn{3}{|c|}{ FoxP3 $^{+}$T-lymphocyte } \\
\hline & $\begin{array}{l}\text { Lowest } \\
\text { tertile }(\%)\end{array}$ & $\begin{array}{l}\text { All others } \\
(\%)\end{array}$ & $p$ value $^{\mathrm{a}}$ & $\begin{array}{l}\text { Absent } \\
(\%)\end{array}$ & $\begin{array}{l}\text { Present } \\
(\%)\end{array}$ & $p$ value $^{\mathrm{a}}$ & $\begin{array}{l}\text { Absent } \\
(\%)\end{array}$ & $\begin{array}{l}\text { Present } \\
(\%)\end{array}$ & $p$ value $^{\mathrm{a}}$ \\
\hline \multicolumn{10}{|l|}{ Age (years) } \\
\hline$<59$ & $43(38.7)$ & $68(61.3)$ & 0.101 & $61(55.0)$ & $50(45.0 \%)$ & 0.571 & $48(44.9)$ & $59(55.1)$ & 0.575 \\
\hline$\geq 59$ & $33(28.4)$ & $83(71.6)$ & & $62(51.2)$ & $59(48.8)$ & & $54(48.6)$ & $57(51.4)$ & \\
\hline \multicolumn{10}{|l|}{ FIGO stage } \\
\hline Stage I/II & $25(33.3)$ & $50(66.7)$ & 0.947 & $45(59.2)$ & $31(40.8 \%)$ & 0.173 & $39(57.4)$ & $29(42.6)$ & 0.031 \\
\hline Stage III/IV & $51(33.8)$ & $100(66.2)$ & & 77 (49.7) & $78(50.3)$ & & $62(41.6)$ & $87(58.4)$ & \\
\hline \multicolumn{10}{|l|}{ Tumor type } \\
\hline Serous & $37(30.3)$ & $85(69.7)$ & 0.278 & $68(52.7)$ & $61(47.3)$ & 0.917 & $51(42.1)$ & $70(57.9)$ & 0.125 \\
\hline Non-serous & $39(37.1)$ & $66(62.9)$ & & $55(53.4)$ & $48(46.6)$ & & $51(52.6)$ & $46(47.4)$ & \\
\hline \multicolumn{10}{|l|}{ Differentiation grade } \\
\hline Grade I/II & $39(37.5)$ & $65(62.5)$ & 0.208 & $56(54.9)$ & $46(45.1)$ & 0.513 & $55(57.3)$ & $41(42.7)$ & 0.011 \\
\hline Grade III and undiff. & $32(29.4)$ & $77(70.6)$ & & $57(50.4)$ & $56(49.6)$ & & $43(39.4)$ & $66(60.6)$ & \\
\hline \multicolumn{10}{|l|}{ Residual disease } \\
\hline$<2 \mathrm{~cm}$ & $45(36.0)$ & $80(64.0)$ & 0.692 & $64(48.9)$ & $67(51.1)$ & 0.109 & $58(50.4)$ & $57(49.6)$ & 0.577 \\
\hline$\geq 2 \mathrm{~cm}$ & $28(33.3)$ & $56(66.7)$ & & $51(60.0)$ & $34(40.0)$ & & $39(46.4)$ & $45(53.6)$ & \\
\hline \multicolumn{10}{|l|}{ CD8 ${ }^{+}$T-lymphocyte } \\
\hline Lowest tertile & & & & $55(76.4)$ & $17(23.6)$ & $<0.001$ & $53(75.7)$ & $17(24.3)$ & $<0.001$ \\
\hline All others & & & & $58(42.0)$ & $80(58.0)$ & & $47(32.9)$ & $96(67.1)$ & \\
\hline \multicolumn{10}{|c|}{ CD45R0 $0^{+} \mathrm{T}$-lymphocyte } \\
\hline Absent & & & & & & & $66(70.2)$ & $41(37.6)$ & $<0.001$ \\
\hline Present & & & & & & & $28(29.8)$ & $68(62.4)$ & \\
\hline \multicolumn{10}{|l|}{$\mathrm{CD}^{+} / \mathrm{FoxP}^{+}$ratio } \\
\hline Bottom tertile & & & & $41(63.1)$ & $24(26.9)$ & 0.038 & & & \\
\hline All others & & & & $64(47.4)$ & $71(52.6)$ & & & & \\
\hline \multicolumn{10}{|l|}{$\mathrm{CD}^{+} / \mathrm{CD} 45 \mathrm{R} 0^{+}$ratio } \\
\hline Bottom tertile & & & & & & & $50(64.1)$ & $28(35.9)$ & $<0.001$ \\
\hline All others & & & & & & & $43(35.5)$ & $78(64.5)$ & \\
\hline
\end{tabular}

FIGO International Federation of Gynaecology and Obstetrics

${ }^{a} p$ values were calculated using Pearson $\chi^{2}$ test

Bold signifies $p<0.05$

TIL in omental metastases, which are by definition present only in patients with advanced stage disease, showed an increased survival in patients with intra-tumoral FoxP3 ${ }^{+}$ Treg (25.6 vs. 14.7 months, $p<0.008$, Fig. $2 \mathrm{~g}$ ) and $\mathrm{CD} 45 \mathrm{R} 0^{+}$memory T-lymphocytes $(24.3$ vs. 15.6 months, $p=0.031$, Fig. 2h).

Multivariate analysis was performed stratified for type of chemotherapy. For all patients as well as the advanced stage subgroup, the above-mentioned well-known prognostic factors and tumor-infiltrating T-lymphocytes were entered into the Cox proportional hazards model (Table 4). In the analysis using all patients, $\mathrm{CD} 8^{+}$lymphocytes and $\mathrm{CD}^{+} / \mathrm{FoxP}^{+}$ratio were independent prognostic factors for DSS (HR 0.36, 95\% CI 0.22-0.59, $p<0.001$; respectively, HR $0.53,95 \%$ CI $0.32-0.85, p=0.009$ ), next to commonly acknowledged risk factors as stage of disease, differentiation grade and amount of residual tumor after primary debulking surgery. When analyzing only patients with advanced stage disease, a high number of $\mathrm{CD}^{+}$cytotoxic lymphocytes in ovarian-derived tumor tissue was demonstrated to be an independent prognostic factor for longer DSS (HR 0.35, 95\% CI 0.21-0.60, $p<0.001$ ), as was the presence of $\mathrm{FoxP}^{+}$Treg (HR 0.55, 95\% CI 0.34-0.88, $p=0.013$ ). Additionally, multivariate analysis was performed using the absolute number of tumor-infiltrating Tlymphocytes in stead of the dichotomized variables (data not shown). Unlike $\mathrm{CD}^{+}$lymphocytes, $\mathrm{FoxP}^{+}$lymphocytes infiltrating tumor epithelium remained an independent factor for longer DSS (HR 0.937, 95\% CI 0.88-1.00, $p=0.035$ ). 
Table 3 Relationship of tumor-infiltrating lymphocytes in omental tissue to clinicopathological parameters and each other $(N, \%)$

\begin{tabular}{|c|c|c|c|c|c|c|c|c|c|}
\hline & \multicolumn{3}{|c|}{ CD8 ${ }^{+}$T-lymphocyte } & \multicolumn{3}{|c|}{ CD45R0 $0^{+}$T-lymphocyte } & \multicolumn{3}{|c|}{ FoxP3 $^{+}$T-lymphocyte } \\
\hline & $\begin{array}{l}\text { Lowest } \\
\text { tertile }(\%)\end{array}$ & $\begin{array}{l}\text { All others } \\
(\%)\end{array}$ & $p$ value $^{\mathrm{a}}$ & $\begin{array}{l}\text { Absent } \\
(\%)\end{array}$ & $\begin{array}{l}\text { Present } \\
(\%)\end{array}$ & $p$ value $^{\mathrm{a}}$ & $\begin{array}{l}\text { Lowest } \\
\text { tertile }(\%)\end{array}$ & $\begin{array}{l}\text { All others } \\
(\%)\end{array}$ & $p$ value $^{\mathrm{a}}$ \\
\hline \multicolumn{10}{|l|}{ Age (years) } \\
\hline$<59$ & $28(38.4)$ & $45(61.6)$ & 0.173 & $38(53.5)$ & $33(46.5)$ & 0.495 & $28(39.4)$ & $43(60.6)$ & 0.653 \\
\hline$\geq 59$ & $16(27.1)$ & $43(72.9)$ & & $30(47.6)$ & $33(52.4)$ & & $21(35.6)$ & $38(64.4)$ & \\
\hline \multicolumn{10}{|l|}{ Tumor type } \\
\hline Serous & $32(33.3)$ & $64(66.7)$ & 1,000 & $52(54.7)$ & $43(45.3)$ & 0.149 & $38(40.4)$ & $56(59.6)$ & 0.299 \\
\hline Non-serous & $12(33.3)$ & $24(66.7)$ & & $16(41.0)$ & $23(59.0)$ & & $11(30.6)$ & $25(69.4)$ & \\
\hline \multicolumn{10}{|l|}{ Differentiation grade } \\
\hline Grade I/II & $12(41.4)$ & $17(58.6)$ & 0.244 & $15(51.7)$ & $14(48.3)$ & 0.871 & $12(42.9)$ & $16(57.1)$ & 0.356 \\
\hline Grade III and undiff. & $28(29.8)$ & $66(70.2)$ & & $47(50.0)$ & $47(50.0)$ & & $31(33.3)$ & $62(66.7)$ & \\
\hline \multicolumn{10}{|l|}{ Residual disease } \\
\hline$<2 \mathrm{~cm}$ & 7 (18.9) & $30(81.1)$ & 0.035 & $18(46.2)$ & $21(53.8)$ & 0.488 & $8(22.2)$ & $28(77.8)$ & 0.028 \\
\hline$\geq 2 \mathrm{~cm}$ & $34(38.2)$ & $55(61.8)$ & & $47(52.8)$ & $42(47.2)$ & & $38(43.2)$ & $50(56.8)$ & \\
\hline \multicolumn{10}{|l|}{ CD8 ${ }^{+}$T-lymphocyte } \\
\hline Lowest tertile & & & & $35(79.5)$ & $9(20.5)$ & $<0.001$ & $29(59.2)$ & $14(17.5)$ & $<0.001$ \\
\hline All others & & & & $29(34.5)$ & $55(65.5)$ & & $20(40.8)$ & $66(82.5)$ & \\
\hline \multicolumn{10}{|c|}{$\mathrm{CD} 45 \mathrm{R} 0^{+} \mathrm{T}$ - lymphocyte } \\
\hline Absent & & & & & & & $36(73.5)$ & $27(34.6)$ & $<0.001$ \\
\hline Present & & & & & & & $13(26.5)$ & $51(65.4)$ & \\
\hline \multicolumn{10}{|l|}{$\mathrm{CD}^{+} / \mathrm{FoxP}^{+}$ratio } \\
\hline Bottom tertile & & & & $28(66.7)$ & $14(33.3)$ & 0.007 & & & \\
\hline All others & & & & $35(41.2)$ & $50(58.8)$ & & & & \\
\hline \multicolumn{10}{|l|}{$\mathrm{CD}^{+} / \mathrm{CD} 45 \mathrm{R} 0^{+}$ratio } \\
\hline Bottom tertile & & & & & & & $34(59.6)$ & $23(40.4)$ & $<0.001$ \\
\hline All others & & & & & & & $22(27.5)$ & $58(72.5)$ & \\
\hline
\end{tabular}

FIGO International Federation of Gynaecology and Obstetrics

${ }^{a} p$ values were calculated using Pearson $\chi^{2}$ test

Bold signifies $p<0.05$

\section{Discussion}

The observation of an improved survival of patients with intra-tumoral T-lymphocytes suggests an important role for the immune system in the natural course of ovarian cancer [33]. In the present study, we analyzed the relative contribution of different tumor-infiltrating T-lymphocyte subtypes to this observed improvement of survival. To our knowledge, this is the first study to examine the prognostic influence of different tumor-infiltrating T-lymphocytes in primary as well as metastatic lesions. We show improved disease-specific survival in advanced stage ovarian cancer patients with $\mathrm{CD} 45 \mathrm{R} 0^{+}$memory $\mathrm{T}$-lymphocytes and/or $\mathrm{FoxP}^{+}$regulatory $\mathrm{T}$-lymphocytes infiltrating ovarianderived tumor tissue and/or omental metastases. In addition, we also confirm important previous observations by others of improved survival in patients with either a high number of tumor-infiltrating $\mathrm{CD}^{+}$cytotoxic T-lymphocytes or a high $\mathrm{CD}^{+} / \mathrm{FoxP}^{+}$ratio [25].
Intra-tumoral $\mathrm{CD}^{2} 5 \mathrm{R}^{+} \mathrm{T}$-lymphocytes, present in approximately $50 \%$ of patients, were associated with increased DSS when present in ovarian-derived tumor tissue and omental metastases. Although its expression is not restricted to memory T-lymphocytes, CD45R0 is commonly used as a marker for memory T-lymphocytes $[4,12$, 21]. Upon antigenic stimulation, naïve T-lymphocytes differentiate into effector T-lymphocytes, but also memory T-lymphocytes can be formed. The latter assure a strong and speedy immune response on subsequent exposures to the same antigen. The presence of tissue-infiltrating memory T-lymphocytes thus implies prior exposure to an antigen encountered in the tissue environment, which in case of tumor-infiltrating memory T-lymphocytes may very well reflect an anti-tumor response of the immune system. The presence of a survival benefit for patients with high levels of infiltrating memory T-lymphocytes was previously described in colorectal cancer $[12,21]$. The cell numbers seen in these studies were remarkably higher than those 

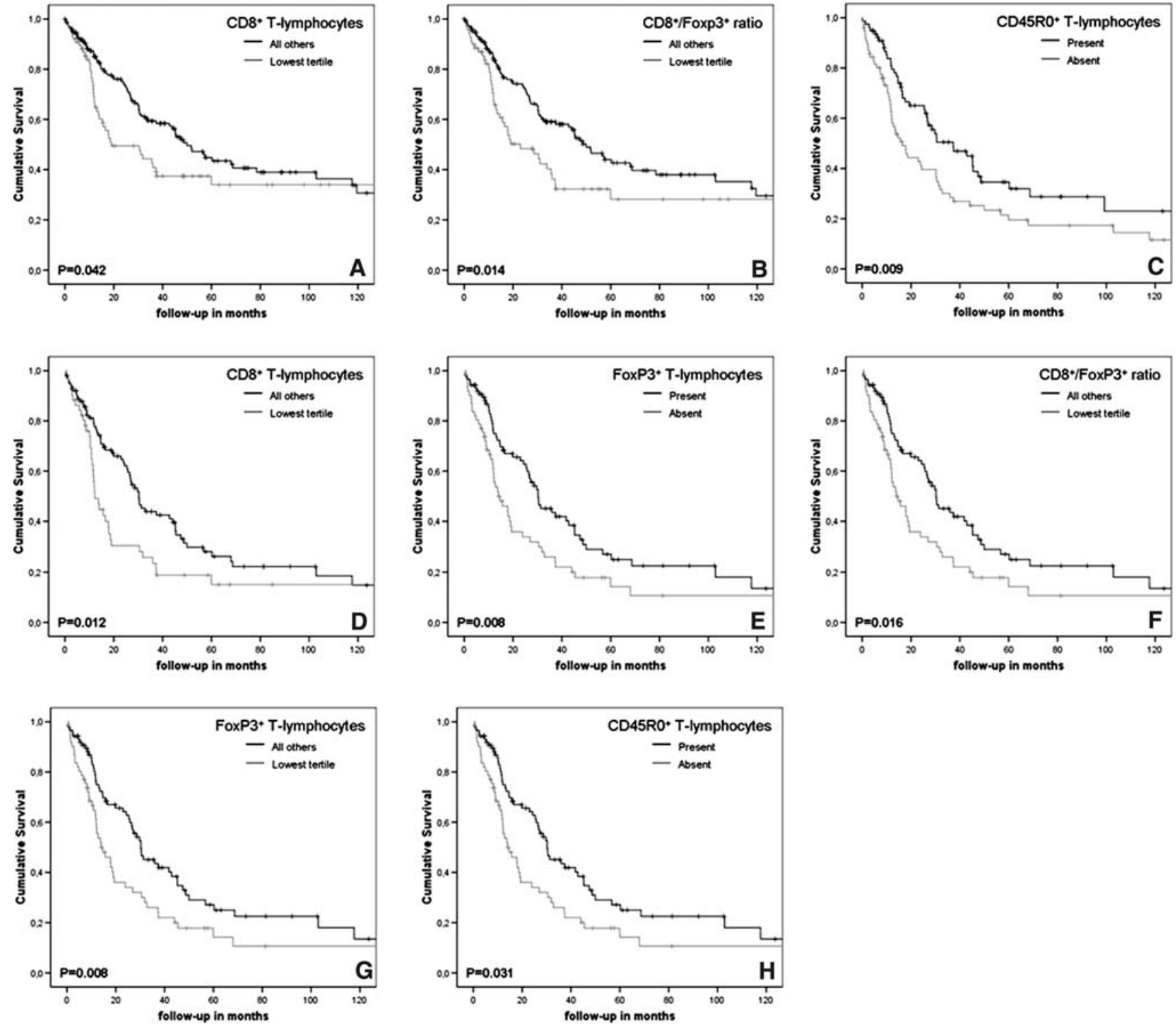

Fig. 2 Disease-specific survival (in months) of ovarian cancer patients based on tumor-infiltrating lymphocytes. Cumulative survival time was estimated by the Kaplan-Meier method. Log Rank test was used to evaluate survival differences between groups. High numbers of $\mathrm{CD} 8^{+} \mathrm{T}$-lymphocytes $(\mathbf{a})$ and a high $\mathrm{CD} 8^{+} / \mathrm{Foxp}^{+}$ratio $(\mathbf{b})$ in ovarianderived tumor tissue were associated with improved survival in FIGO

used in our study (cut-off values $80-250$ cells $/ \mathrm{mm}^{2}$ ), which may be explained in several ways. Firstly, no distinction was made between tumor- and peri-tumoral stroma infiltrating cells in these studies, whereas we only report tumorinfiltrating memory T-lymphocytes. Secondly, when repeating our analysis on the total cell count/core we still did not observe levels similar to that in colorectal cancer, although results for the survival analysis were comparable to the analysis with tumor-infiltrating memory T-lymphocytes only (data not shown). A more likely explanation is that the higher number of infiltrating lymphocytes in colon tissue stage I-IV disease. In advanced stage patients, a survival benefit was observed for patients with CD45R0 $0^{+} \mathrm{T}$-lymphocytes (c) $\mathrm{CD}^{+} \mathrm{T}-1 \mathrm{ym}$ phocytes (d), FoxP $3^{+}$T-lymphocytes $(\mathbf{e})$ a high $\mathrm{CD} 8^{+} / \mathrm{FoxP}^{+}$ratio $(\mathbf{f})$ in ovarian-derived tumor tissue. Furthermore, $\mathrm{FoxP}^{+}(\mathbf{g})$ and CD45R0 ${ }^{+} \mathrm{T}$-lymphocytes (h) in omental metastases were associated with improved disease-specific survival

could be considered inherent to its daily exposure to foreign products and pathogens, an observation which does not hold for ovarian tissue.

Our data show that patients with intra-tumoral CTL infiltrations and/or a high CTL/Treg ratio in tumor-containing ovarian tissue consistently have the longest disease-specific survival, confirming the results previously described in a smaller population of ovarian cancer patients [25]. However, unlike previous studies in ovarian cancer addressing the prognostic influence of Treg [9, 25], we found tumorinfiltrating Treg to be an independent positive factor for 
Table 4 Multivariate Cox regression analysis on disease-specific survival

\begin{tabular}{|c|c|c|c|c|c|c|c|c|c|}
\hline & HR & $95 \% \mathrm{CI}$ & $p$ value & HR & $95 \% \mathrm{CI}$ & $p$ value & HR & $95 \% \mathrm{CI}$ & $p$ value \\
\hline \multicolumn{10}{|l|}{ All stages } \\
\hline Age $\geq 59$ years & 0.96 & $0.60-1.55$ & 0.876 & 0.98 & $0.61-1.59$ & 0.938 & & & \\
\hline FIGO Stage III/IV & 3.31 & $1.34-8.13$ & 0.009 & 3.59 & $1.73-9.37$ & 0.009 & & & \\
\hline Grade III/undifferentiated & 1.97 & $1.19-3.27$ & 0.008 & 1.64 & $0.98-2.74$ & 0.059 & & & \\
\hline Non-serous tumor & 0.67 & $0.41-1.12$ & 0.125 & 0.63 & $0.38-1.05$ & 0.078 & & & \\
\hline Residual tumor & 3.38 & $2.27-6.44$ & $<0.001$ & 3.01 & $1.82-4.96$ & $<0.001$ & & & \\
\hline $\mathrm{CD}^{+}$T-lymphocytes high $(\mathrm{OV})$ & 0.36 & $0.22-0.59$ & $<0.001$ & & & & & & \\
\hline $\mathrm{CD}^{+} / \mathrm{FoxP}^{+}$ratio high $(\mathrm{OV})$ & & & & 0.53 & $0.32-0.85$ & 0.009 & & & \\
\hline \multicolumn{10}{|l|}{ Advanced stage only } \\
\hline Age $\geq 59$ years & 0.82 & $0.50-1.36$ & 0.444 & 1.02 & $0.63-1.64$ & 0.945 & 0.99 & $0.60-1.64$ & 0.979 \\
\hline Grade III/undifferentiated & 1.75 & $1.02-2.99$ & 0.041 & 1.82 & $1.07-3.09$ & 0.026 & 1.69 & $0.96-2.97$ & 0.067 \\
\hline Non-serous tumor & 0.76 & $0.44-1.30$ & 0.309 & 0.77 & $0.44-1.33$ & 0.346 & 0.72 & $0.42-1.23$ & 0.229 \\
\hline Residual tumor & 3.58 & $2.08-6.17$ & $<0.001$ & 2.41 & $1.50-3.88$ & $<0.001$ & 2.56 & $1.54-4.25$ & $<0.001$ \\
\hline $\mathrm{CD}^{+}$T-lymphocytes high (OV) & 0.35 & $0.21-0.60$ & $<0.001$ & & & & & & \\
\hline $\mathrm{CD} 45 \mathrm{R} 0^{+} \mathrm{T}$-lymphocytes present $(\mathrm{OV})$ & & & & 0.72 & $0.46-1.14$ & 0.166 & & & \\
\hline FoxP3 $^{+}$T-lymphocytes present $(\mathrm{OV})$ & & & & & & & 0.55 & $0.34-0.88$ & 0.013 \\
\hline Age $\geq 59$ years & 1.00 & $0.61-1.65$ & 1.000 & 0.76 & $0.43-1.33$ & 0.888 & 0.76 & $0.44-1.33$ & 0.335 \\
\hline Grade III/undifferentiated & 1.42 & $0.83-2.44$ & 0.205 & 1.04 & $0.57-1.89$ & 0.910 & 1.29 & $0.70-2.37$ & 0.417 \\
\hline Non-serous tumor & 0.76 & $0.44-1.30$ & 0.318 & 0.60 & $0.34-1.06$ & 0.078 & 0.66 & $0.37-1.20$ & 0.177 \\
\hline Residual tumor & 2.50 & $1.51-4.15$ & $<0.001$ & 2.63 & $1.41-4.90$ & 0.002 & 2.74 & $1.46-5.15$ & 0.002 \\
\hline $\mathrm{CD}^{+} / \mathrm{FoxP}^{+}$ratio high $(\mathrm{OV})$ & 0.68 & $0.42-1.08$ & 0.099 & & & & & & \\
\hline $\mathrm{CD} 45 \mathrm{R} 0^{+} \mathrm{T}$-lymphocytes present $(\mathrm{OM})$ & & & & 0.69 & $0.43-1.08$ & 0.106 & & & \\
\hline FoxP3 $^{+}$T-lymphocytes high (OM) & & & & & & & 0.64 & $0.39-1.06$ & 0.082 \\
\hline
\end{tabular}

Analyses were performed stratified for type of chemotherapy. FIGO International Federation of Gynecology and Obstetrics, HR hazard ratio, $C I$ confidence interval, $O V$ ovarian-derived tumor tissue, $O M$ omental metastasis

Bold signifies $p<0.05$

disease-specific survival in patients with advanced stage disease. One possible explanation is the fact that although FoxP3 is currently the best marker available for immunohistochemical staining of Treg on paraffin embedded tissue, it is not exclusively expressed in regulatory cells. Recently, it was shown that activated $\mathrm{CD} 4^{+} \mathrm{CD} 25^{-}$effector $\mathrm{T}$ cells transiently express FoxP3, without having regulatory activity $[2,23]$. Possibly, the positive prognostic effect of the presence of FoxP $3^{+}$cells in our samples can be attributed to the staining of not only suppressive, but also activated T-lymphocytes expressing FoxP3. Similar observations of positive effects of Treg however, have been previously reported in studies on immune cell malignancies and head and neck squamous cell carcinoma (HNSCC), some of which further phenotyped the FoxP3 ${ }^{+}$cells. A high number of Treg is associated to longer survival in follicular lymphoma and classic Hodgkin's lymphoma [3, 18]. In HNSCC where higher numbers of circulating Treg were present in patients without evidence of disease after primary treatment compared to patients with active disease, locoregional Treg were associated with better locoregional control [5, 28]. Furthermore, the possible protective role for
Treg against cancer was also illustrated in murine models of colorectal cancer, which show that adoptive transfer of $\mathrm{CD} 4{ }^{+} \mathrm{CD} 25^{+}$regulatory cells results in regression of adenomas $[10,11]$. Although we find that the presence of Treg is associated with an increase in disease-specific survival, we also find that (1) the absolute number of Treg present does not seem to alter this positive prognostic effect, (2) the presence of Treg is strongly associated with high numbers of CTL, and (3) a high CTL/Treg ratio is associated with a longer disease-specific survival. It thus seems plausible that it is not merely the presence of Treg, but rather the infiltration of tumor by T-lymphocytes in general which is responsible for the observed survival advantage, as was previously reported by Zhang et al. [33]. In this point of view, infiltration of tumor epithelium, or any other inflammatory site, by lymphocytes is naturally accompanied by regulatory $\mathrm{T}$ cells and the effectiveness of immune responses depends on the proportion of the different lymphocyte subtypes present instead of on the presence of a particular subtype.

Unlike previous studies of TIL in ovarian cancer, we have also studied the prognostic influence of TIL in omental metastases of ovarian cancer patients. Although TIL in 
omental metastases were not independent predictors of disease-specific survival, we did show an increased survival in univariate analysis for advanced stage patients with memory T-lymphocytes and Treg infiltrating omental metastases. Interestingly, median numbers of TIL were higher in omental metastases than in ovarian-derived tumor tissue and the percentage of patients with Treg in omental metastases was substantially higher than for ovarian-derived tumor tissue. The omentum may be considered a secondary lymphoid tissue as it contains large aggregates of macrophages and lymphocytes, the so-called milky spots. These milky spots contain mostly macrophages (68\%), but T-lymphocytes are also present (10\%) [17]. The high percentage of patients with Treg observed in omental metastases and the higher median cell counts as compared to ovarianderived tumor tissue may be a reflection of the lymphoid function of the omentum.

In summary, we show that memory T-lymphocytes infiltrating ovarian-derived tumor tissue and omental metastases are associated with increased disease-specific survival in patients with advanced stage disease. Unexpectedly, the presence of regulatory T-lymphocytes in ovarian-derived tumor tissue is also an independent factor for increased disease-specific survival. However, the fact that a high CTL/ Treg ratio independently predicts increased survival as well, suggests that it is not so much the presence of Treg as the presence of TIL in general that is responsible for the observed survival effect. Our results support the notion that different T-lymphocyte subsets play a unique and important role in the natural course of ovarian cancer.

Acknowledgment Funding: Dutch Cancer Society Grant 2002-2768 (H. W. Nijman) and 2007-3919 (N. Leffers/H. W. Nijman).

Conflict of interest statement The authors declare that there are no conflicts of interest.

Open Access This article is distributed under the terms of the Creative Commons Attribution Noncommercial License which permits any noncommercial use, distribution, and reproduction in any medium, provided the original author(s) and source are credited.

\section{References}

1. Agarwal R, Linch M, Kaye SB (2006) Novel therapeutic agents in ovarian cancer. Eur J Surg Oncol 32:875-886

2. Allan S, Crome S, Crellin N, Passerini L, Steiner T, Bacchetta R, Roncarolo M, Levings M (2007) Activation-induced FOXP3 in human $\mathrm{T}$ effector cells does not suppress proliferation or cytokine production. Int Immunol 19:345-354

3. Alvaro T, Lejeune M, Salvado MT, Bosch R, Garcia JF, Jaen J, Banham AH, Roncador G, Montalban C, Piris MA (2005) Outcome in Hodgkin's lymphoma can be predicted from the presence of accompanying cytotoxic and regulatory $\mathrm{T}$ cells. Clin Cancer Res 11:1467-1473
4. Anraku M, Cunningham K, Yun Z, Tsao M, Zhang L, Keshavjee S, Johnston M, de Perrot M (2008) Impact of tumor-infiltrating T cells on survival in patients with malignant pleural mesothelioma. J Thorac Cardiovasc Surg 135:823-829

5. Badoual C, Hans S, Rodriguez J, Peyrard S, Klein C, Agueznay NH, Mosseri V, Laccourreye O, Bruneval P, Fridman WH, Brasnu DF, Tartour E (2006) Prognostic value of tumor-infiltrating CD $4^{+}$ T-cell subpopulations in head and neck cancers. Clin Cancer Res 12:465-472

6. Cai XY, Gao Q, Qiu SJ, Ye SL, Wu ZQ, Fan J, Tang ZY (2006) Dendritic cell infiltration and prognosis of human hepatocellular carcinoma. J Cancer Res Clin Oncol 132:293-301

7. Cancer Committee of the International Federation of Gynaecology and Obstetrics (1986) Staging announcement: FIGO Cancer Committee. Gynecol Oncol 25:383-385

8. Clemente CG, Mihm MC Jr, Bufalino R, Zurrida S, Collini P, Cascinelli N (1996) Prognostic value of tumor infiltrating lymphocytes in the vertical growth phase of primary cutaneous melanoma. Cancer 77:1303-1310

9. Curiel TJ, Coukos G, Zou L, Alvarez X, Cheng P, Mottram P, Evdemon-Hogan M, Conejo-Garcia JR, Zhang L, Burow M, Zhu Y, Wei S, Kryczek I, Daniel B, Gordon A, Myers L, Lackner A, Disis ML, Knutson KL, Chen L, Zou W (2004) Specific recruitment of regulatory $\mathrm{T}$ cells in ovarian carcinoma fosters immune privilege and predicts reduced survival. Nat Med 10:942-949

10. Erdman S, Poutahidis T, Tomczak M, Rogers A, Cormier K, Plank B, Horwitz B, Fox J (2003) CD4 ${ }^{+} \mathrm{CD} 25^{+}$regulatory T lymphocytes inhibit microbially induced colon cancer in Rag2-deficient mice. Am J Pathol 162:691-702

11. Erdman S, Sohn J, Rao V, Nambiar P, Ge Z, Fox J, Schauer D (2005) $\mathrm{CD}^{+} \mathrm{CD} 25^{+}$regulatory lymphocytes induce regression of intestinal tumors in ApcMin/+ Mice. Cancer Res 65:3998-4004

12. Galon J, Costes A, Sanchez-Cabo F, Kirilovsky A, Mlecnik B, Lagorce-Pages C, Tosolini M, Camus M, Berger A, Wind P, Zinzindohoue F, Bruneval P, Cugnenc PH, Trajanoski Z, Fridman WH, Pages F (2006) Type, density, and location of immune cells within human colorectal tumors predict clinical outcome. Science 313:1960-1964

13. Greenlee RT, Hill-Harmon MB, Murray T, Thun M (2001) Cancer statistics. CA Cancer J Clin 51:15-36

14. Halpern AC, Schuchter LM (1997) Prognostic models in melanoma. Semin Oncol 24:S2-S7

15. Kondratiev S, Sabo E, Yakirevich E, Lavie O, Resnick MB (2004) Intratumoral $\mathrm{CD}^{+} \mathrm{T}$ lymphocytes as a prognostic factor of survival in endometrial carcinoma. Clin Cancer Res 10:4450-4456

16. Kononen J, Bubendorf L, Kallioniemi A, Barlund M, Schraml P, Leighton S, Torhorst J, Mihatsch MJ, Sauter G, Kallioniemi OP (1998) Tissue microarrays for high-throughput molecular profiling of tumor specimens. Nat Med 4:844-847

17. Krist LF, Eestermans IL, Steenbergen JJ, Hoefsmit EC, Cuesta MA, Meyer S, Beelen RH (1995) Cellular composition of milky spots in the human greater omentum: an immunochemical and ultrastructural study. Anat Rec 241:163-174

18. Lee A, Clear A, Calaminici M, Davies A, Jordan S, MacDougall F, Matthews J, Norton A, Gribben J, Lister TA, Goff L (2006) Number of $\mathrm{CD}^{+}$cells and location of Forkhead Box Protein P3positive cells in diagnostic follicular lymphoma tissue microarrays correlates with outcome. J Clin Oncol 24:5052-5059

19. Naito Y, Saito K, Shiiba K, Ohuchi A, Saigenji K, Nagura H, Ohtani H (1998) CD8 ${ }^{+} \mathrm{T}$ cells infiltrated within cancer cell nests as a prognostic factor in human colorectal cancer. Cancer Res 58:3491-3494

20. Nakano O, Sato M, Naito Y, Suzuki K, Orikasa S, Aizawa M, Suzuki Y, Shintaku I, Nagura H, Ohtani H (2001) Proliferative activity of intratumoral CD8(+) T-lymphocytes as a prognostic 
factor in human renal cell carcinoma: clinicopathologic demonstration of antitumor immunity. Cancer Res 61:5132-5136

21. Pages F, Berger A, Camus M, Sanchez-Cabo F, Costes A, Molidor R, Mlecnik B, Kirilovsky A, Nilsson M, Damotte D, Meatchi T, Bruneval P, Cugnenc PH, Trajanoski Z, Fridman WH, Galon J (2005) Effector memory T cells, early metastasis, and survival in colorectal cancer. N Engl J Med 353:2654-2666

22. Parkin DM, Bray F, Ferlay J, Pisani P (2005) Global cancer statistics, 2002. CA Cancer J Clin 55:74-108

23. Roncarolo MG, Gregori S (2008) Is FOXP3 a bona fide marker for human regulatory T cells? Eur J Immunol 38:925-927

24. Rosen DG, Huang X, Deavers MT, Malpica A, Silva EG, Liu J (2004) Validation of tissue microarray technology in ovarian carcinoma. Mod Pathol 17:790-797

25. Sato E, Olson SH, Ahn J, Bundy B, Nishikawa H, Qian F, Jungbluth AA, Frosina D, Gnjatic S, Ambrosone C, Kepner J, Odunsi T, Ritter G, Lele S, Chen YT, Ohtani H, Old LJ, Odunsi K (2005) Intraepithelial $\mathrm{CD}^{+}$tumor-infiltrating lymphocytes and a high $\mathrm{CD}^{+} /$regulatory $\mathrm{T}$ cell ratio are associated with favorable prognosis in ovarian cancer. Proc Natl Acad Sci USA 102:18538-18543

26. Schumacher K, Haensch W, Roefzaad C, Schlag PM (2001) Prognostic significance of activated CD8(+) T cell infiltrations within esophageal carcinomas. Cancer Res 61:3932-3936
27. Scully RE (1999) Histological typing of ovarian tumours. Springer, Berlin

28. Strauss L, Bergmann C, Gooding W, Johnson J, Whiteside T (2007) The frequency and suppressor function of $\mathrm{CD} 4^{+} \mathrm{CD} 25 \mathrm{highFoxp}^{+} \mathrm{T}$ cells in the circulation of patients with squamous cell carcinoma of the head and neck. Clin Cancer Res 13:6301-6311

29. Vesalainen S, Lipponen P, Talja M, Syrjanen K (1994) Histological grade, perineural infiltration, tumour-infiltrating lymphocytes and apoptosis as determinants of long-term prognosis in prostatic adenocarcinoma. Eur J Cancer 30A:1797-1803

30. Wolf D, Wolf AM, Rumpold H, Fiegl H, Zeimet AG, MullerHolzner E, Deibl M, Gastl G, Gunsilius E, Marth C (2005) The expression of the regulatory $\mathrm{T}$ cell-specific forkhead box transcription factor FoxP3 is associated with poor prognosis in ovarian cancer. Clin Cancer Res 11:8326-8331

31. World Health Organization (1979) Handbook for reporting results of cancer treatment. World Health Organization, Geneva

32. Yu P, Fu YX (2006) Tumor-infiltrating T lymphocytes: friends or foes? Lab Invest 86:231-245

33. Zhang L, Conejo-Garcia JR, Katsaros D, Gimotty PA, Massobrio M, Regnani G, Makrigiannakis A, Gray H, Schlienger K, Liebman MN, Rubin SC, Coukos G (2003) Intratumoral T cells, recurrence, and survival in epithelial ovarian cancer. N Engl J Med 348:203-213 